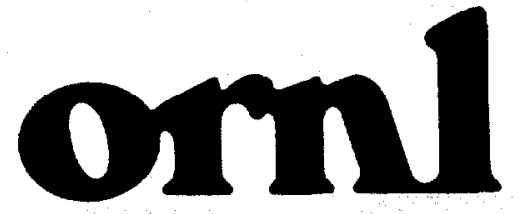

OAK

RIDGE

NATIONAL

LABORATORY

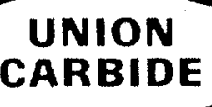

\section{Chemical $\mathrm{Characteristics}$ of Two Forested UItisols and Two Forested Inceptisols Relevant to Anion Production and Mobility}

\author{
D. W. Johnson \\ D. W. Cole \\ F. W. Horng \\ H. Van Miegroet \\ D. E. Todd
}

ENVIRONMENTAL SCIENCES DIVISION Publication No. 1670
DPERATED BY

UNION CABBIDE CORPOBATION FOR THE UNITED STATES DEPARTWEIT OF ENERGY 
Contract No. W-7405-eng-26

\title{
CHEMICAL CHARACTERISTICS OF TWO FORESTED ULTISOLS \\ AND TWO FORESTED INCEPTISOLS RELEVANT TO ANION PRODUCTION AND MOBILITY
}

D. W. Johnson, D. W. Cole,* F. W. Horng, * H. Van Miegroet, $*$ and D. E. Todd 42

\author{
ENVIRONMENTAL SCIENCES DIVISION \\ Publication No. 1670
}

*University of Washington, Seattle

Date Published: June 1981

NOTICE This document contains information of a preliminary nature It is subject to revision or correction and therefore does not rapresert a final report.

OAK RIDGE NATIONAL LABORATORY

Oak Ridge, Tennessee 37830 operated by UNION CARBIDE CORPORATION

for the DEPARTMENT OF ENERGY 



\section{ACKNOWLEDGMENTS}

Research sponsored by the National Science Foundation's Ecosystem Studies Program (DEB-7824395) grant to the University of Washington. Support for ORNL research provided by subcontract from the University of Washington. Many thanks are due Frances 01 szewski at the University of Washington and Marion Ferguson at ORNL for chemical analyses. 


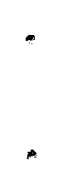


JOHNSON, D. W., D. W. COLE, F. W. HORNG, H. VAN MIEGROET, and D. E. TODD. 1981. Chemical characteristics of two forested U1 tisols and two forested Inceptisols relevant to anion production and mobility. ORNL/TM-7646.

Oak Ridge National Laboratory, Oak Ridge, Tennessee. $30 \mathrm{pp}$.

As a prelude to a basic program on soil leaching, some chemical characteristics of two forested Ultisols in eastern Tennessee and two forested Inceptisols in western Washington are discussed in relation to the production and mobility of anions. These soils were chosen in an attempt to provide a range of free iron ( $\mathrm{Fe}$ ) and aluminum ( $\mathrm{AT}$ ) contents (which are hypothesized to be related to anion adsorption) and carbon:nitrogen ( $C: N)$ ratios (which are hypothesized to be related to nitrate and bicarbonate production) for field experiments involving $C$, $N$, and anion salt additions.

The Washington Inceptisols had high free $\mathrm{Fe}$ and $\mathrm{Al}$ in surface horizons and decreasing free $\mathrm{Fe}$ and $\mathrm{Al}$ levels with depth, whereas the reverse was true of the Tennessee Ultisols. The Alderwood-red alder and Tarklin (sinkhole) soils had higher $\mathrm{N}$ concentrations and lower $\mathrm{C}: \mathrm{N}$ ratios in their surface horizons than the Alderwood-Douglas-fir and Fullerton soils, respectively, but the reverse was true of subsurface horizons. Patterns of and relationships among the above properties and $\mathrm{pH}$, Bray phosphorus (No. 2); adsorbed and soluble $\mathrm{SO}_{4}^{2-}, \mathrm{Cl}^{-}$, and $\mathrm{NO}_{3}^{-}$; cation exchange capacity; and exchangeable cations are discussed. 


\section{TABLE OF CONTENTS}

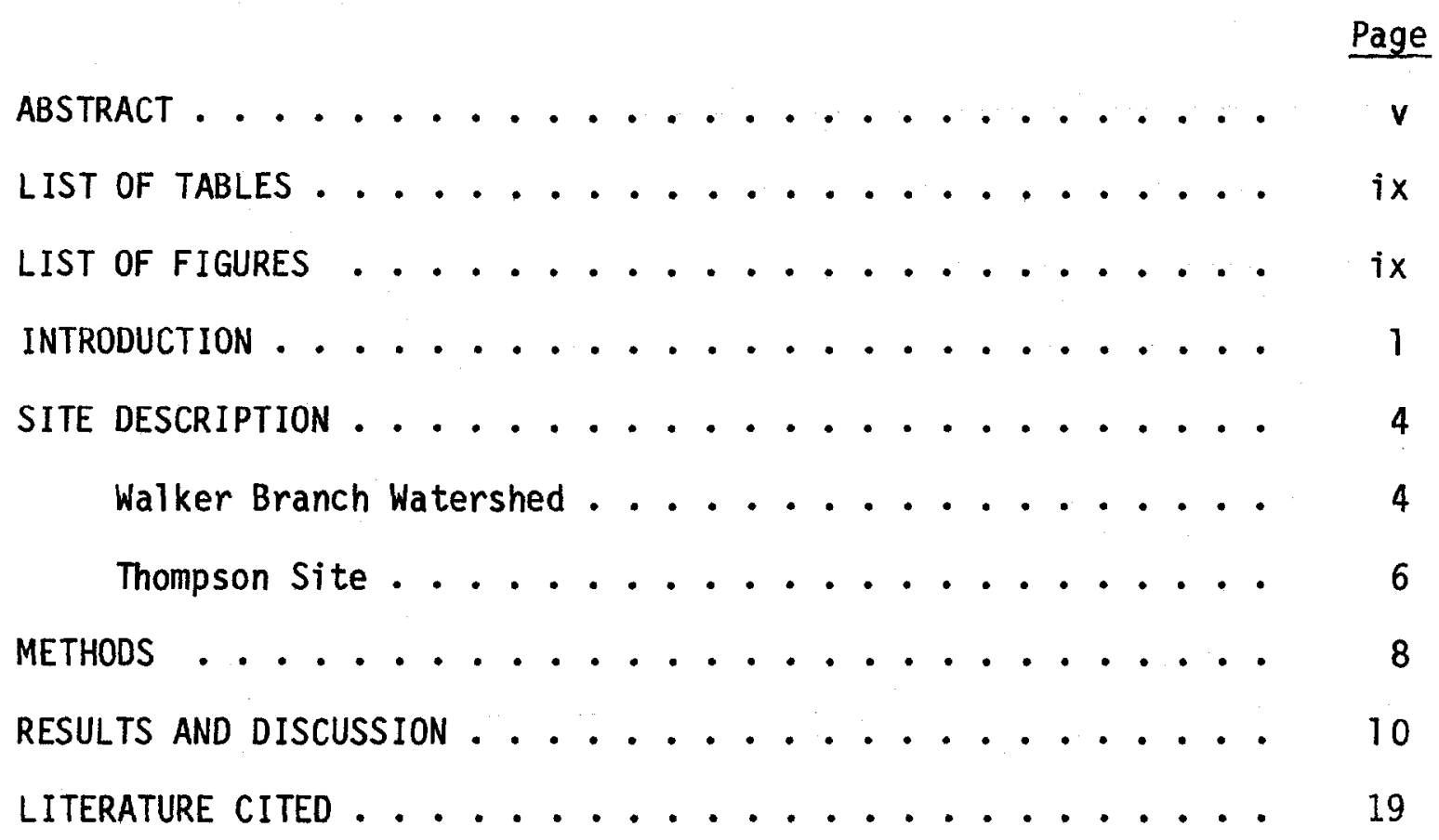




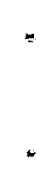


1 Profile description of Fullerton series soil ....... 5

2 Profile description of Tarklin series soil . . . . . . 7

3 Profile description of Alderwood series soil ....... 9

4 Methods used in soil chemical analyses .......... 11

5 Values for $\mathrm{pH}$, free $\mathrm{Fe}$ and $A 1$, Bray $P$ and anion concentrations in soils from the Oak Ridge sites ..... 12

6 Values for $\mathrm{pH}$, free $\mathrm{Fe}$ and $\mathrm{Al}$, Bray $\mathrm{P}$ and anion concentrations in soils from the Thompson sites . . . . 12

7 Bulk density $(\mathrm{Db})$, percent grave1, N, C, C:N ratio, cation exchange capacity (CEC), exchangeable cations, and percent base saturation (BS) in soils from the

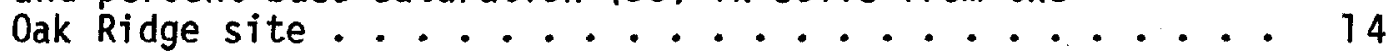

8 Bulk density $(\mathrm{Db})$, percent gravel, $N, C, C: N$ ratio, cation exchange capacity (CEC), exchangeable cations, and percent base saturation (BS) in soils from the Thompson site... . 14

9 Percent free $\mathrm{Fe}, \mathrm{Al}, \mathrm{C}$, and $\mathrm{N}$ in Tarkl in, Fullerton, and Alderwood soils on a whole-soil basis ........ 18

\section{LIST OF FIGURES}

1 Schematic diagram of hypothesized production and mobilities of major anions as a function of soil weathering and available $\mathrm{C}: \mathrm{N}$ ratio........... 


\section{INTRODUCTION}

The purpose of this report is to describe some chemical and physical properties of four forest soils, two on the Walker Branch Watershed in Tennessee and two at the Thompson Site in Washington. These sites are involved in a joint University of Washington - Oak Ridge National Laboratory (ORNL) study of soil leaching processes funded by the National Science Foundation. The data reported herein can be used as a reference for this and future studies at both sites.

The central hypothesis of the current research is that elemental leaching losses from forest ecosystems can be predicted by understanding and quantifying those processes that regulate anion production and mobility within the soil component. We propose to test this hypothesis with a series of experiments in two forest ecosystems, one rich in nitrogen $(N)$ and one poor in $N$, at each of the sites.

This research is designed to test three basic hypotheses:

1. The mobility of sulfate and phosphate in soil is related to the free iron (Fe) and aluminum (Al) content of the soil. This, in turn, is a function of the original chemical composition of the soil parent material and the degree to which it has been weathered.

2. The ratio of nitrate to bicarbonate in the soil solution is regulated in part by the ratio of available $\mathrm{N}$ to available carbon (C) in the soil.

3. Any addition (natural or otherwise) that raises the soil solution $\mathrm{pH}$ will mobilize $\mathrm{HCO}_{3}^{-}$and adsorbed anions and thus shift the anion composition of the soil solution. 
For testing the above hypotheses the major anions have been divided into three categories based upon their general chemical characteristics and interactions in the soil. Because of their tendencies to enter into adsorption reactions, sulfate and phosphate are treated as one category. Nitrate and bicarbonate are combined into a second category because of the heavy influence of biological processes on their production and mobilities. Chloride is treated in the third category because of its relative freedom from both chemical and biological interactions in soils.

Hypotheses 1 through 3 are schematically represented in Fig. 1. A soil at time zero $\left(\mathrm{T}_{0}\right)$ can be visualized as developing along a plane. One axis of the plane is an index of fertility ( $\mathrm{C}: \mathrm{N}$ ratio), and the other axis is the degree of soil weathering. The fertility is regulated by the biological component of the site (i.e., the development of species with $\mathrm{N}$-rich or $\mathrm{N}$-poor foliage). As the detritus from these species decomposes on or in the soil, the chemical makeup (available $\mathrm{C}: \mathrm{N})$ regulates the production of $\mathrm{NO}_{3}^{-}$and $\mathrm{HCO}_{3}^{-}$in the soil. The second axis, degree of soil weathering, is primarily a function of the physical aspects of the site (e.g., rainfall amount and composition, soil parent material), but the biological component plays a strong role as well (e.g., soil $\mathrm{CO}_{2}$ evolution and carbonic acid production). As the soil weathers, proceeding from $T_{0}$ to $T_{n}$, it becomes depleted of bases thus becoming more acid and enriched in sesquioxides. These factors in turn reduce the $\mathrm{pH}$, the mobilities of $\mathrm{SO}_{4}^{2-}$ and $\mathrm{H}_{2} \mathrm{PO}_{4}^{-}$, and the ionization of $\mathrm{HCO}_{3}^{-}$. 


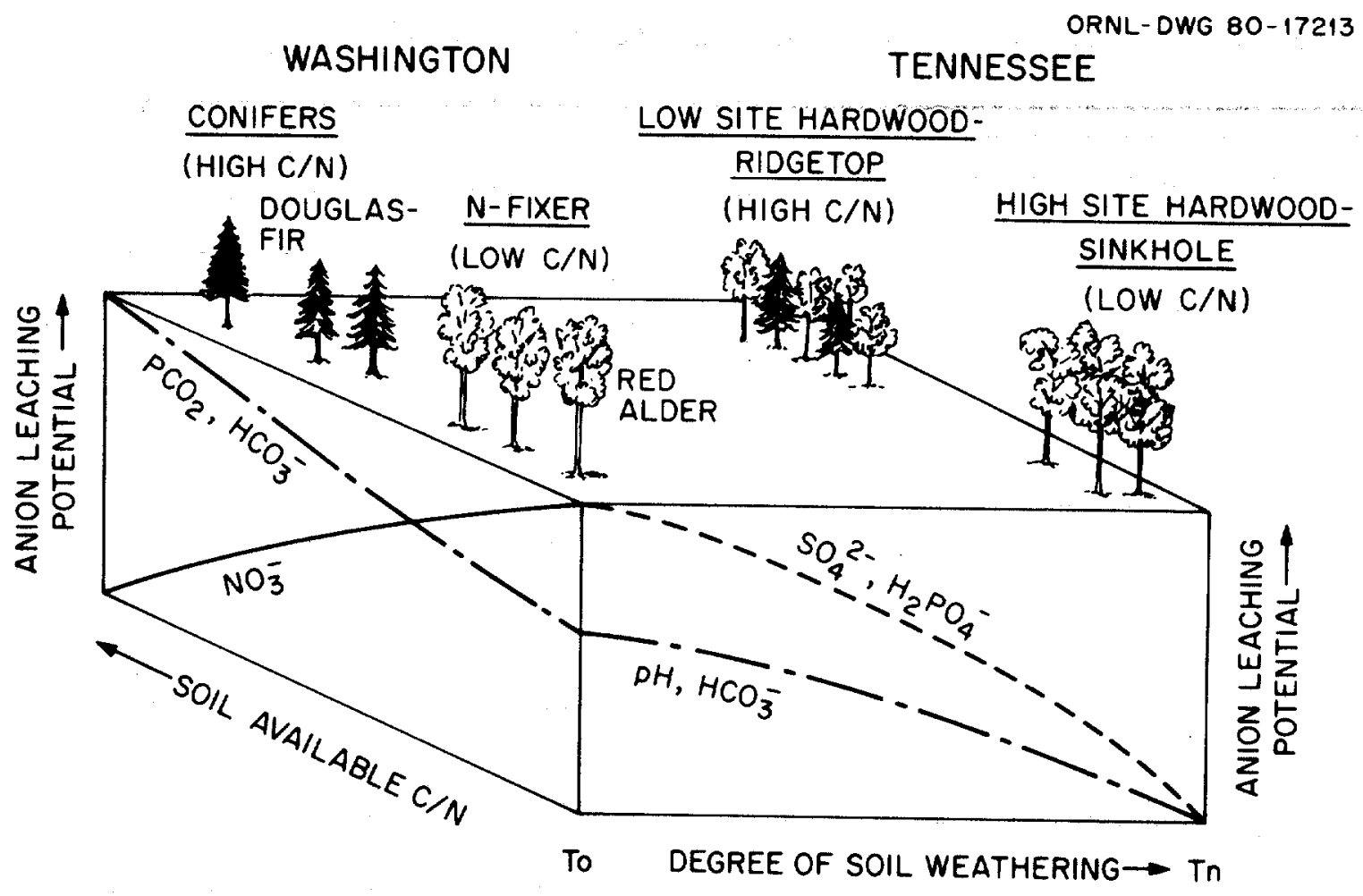

Fig. 1. Schematic diagram of hypothesized production and mobilities of major anions as a function of soil weathering and available $\mathrm{C}: \mathrm{N}$ ratio. 
While the validity of this model cannot be tested directly because it would involve waiting hundreds or thousands of years for the study soil to develop, we have decided to test component hypotheses of this overall model by looking at anion production and mobilities in soils within certain ecosystems whose properties lie on different ends of the axes defined in Fig. 1. In this initial research we will explore leaching processes in forest soils that lie near the four extremes of the surface in Fig. 1. The red alder and Douglas-fir stands represent $\mathrm{N}$-rich and $\mathrm{N}$-poor sites in western Washington where the soils are glacially derived and relatively young. The low- and high-fertility hardwood stands represent $\mathrm{N}-$ rich and $\mathrm{N}$-poor sites in eastern Tennessee, where soils are very old.

\section{SITE DESCRIPTION}

Walker Branch Watershed

Walker Branch Watershed is situated in the ridge and valley physiographic province near Oak Ridge, Tennessee (Grigal and Goldstein, 1971). The climate is of the humid mesothermal type with moderate summer and winter temperatures. Mean annual temperature is $14.3^{\circ} \mathrm{C}$ and precipitation for the 1970-76 period averaged $151 \mathrm{~cm} / \mathrm{yr}$, most of which fell as rain (Henderson et al. 1977). Underlying the watershed is Knox dolomite, a cherty, dense to coarsely crystalline rock of late Cambrian to early Ordovician age.

The low-site hardwood stand on walker Branch is located on a ridgetop on the Fullerton series soil, a Typic Paleudult. A detailed soil description is given in Table 1. Vegetation at the site is of the 
Table 1. Profile description of Fullerton Series Soil

\begin{tabular}{|c|c|c|}
\hline Horizon & $\begin{array}{l}\text { Depth } \\
(\mathrm{cm})\end{array}$ & Description \\
\hline 01 & $5-1 \cdot 5$ & Partially decomposed hardwood litter \\
\hline 02 & $1 \cdot 5-0$ & $\begin{array}{l}\text { Unrecognizably decomposed litter } \\
\text { and humus }\end{array}$ \\
\hline Al & $0-7$ & $\begin{array}{l}\text { Dark grayish-brown ( } 10 \text { yr } 4 / 2) \\
\text { cherty silt loam; moderate fine } \\
\text { granular structure; very friable; } \\
\text { abundant roots; gradual smooth } \\
\text { boundary }\end{array}$ \\
\hline$A 2$ & $7-38$ & $\begin{array}{l}\text { Brown }(10 \text { yr } 5 / 3) \text { cherty loam; weak } \\
\text { fine granular structure; friable; } \\
\text { occassional roots; gradual wavy } \\
\text { boundary }\end{array}$ \\
\hline A3 & $38-42$ & $\begin{array}{l}\text { Light yellowish-brown (10 yr } 6 / 4) \\
\text { cherty loam; weak fine granular } \\
\text { and subangular blocky structure; } \\
\text { friable; occassional roots; gradual } \\
\text { wavy boundary; discontinuous }\end{array}$ \\
\hline B1 & $42-50$ & $\begin{array}{l}\text { Yellowish-brown }(10 \text { yr } 5 / 8) \text { cherty } \\
\text { clay loam; weak medium subangular } \\
\text { blocky structure; firm to friable; } \\
\text { roots rare; gradual wavy boundary }\end{array}$ \\
\hline B21 & $50-80$ & $\begin{array}{l}\text { Yellowish-brown ( } 5 \text { yr } 5 / 8 \text { ) cherty } \\
\text { clay loam; moderate medium angular } \\
\text { blocky structure; firm; gradual } \\
\text { wavy boundary }\end{array}$ \\
\hline B22 & $80+$ & $\begin{array}{l}\text { Red }(2.5 \mathrm{yr} 4 / 8) \text { cherty clay loam; } \\
\text { strong medium angular blocky } \\
\text { structure; very firm. }\end{array}$ \\
\hline
\end{tabular}


oak-hickory type described by Grigal and Goldstein (1971). Species consist primarily of hickory (Carya spp.), red maple (Acer rubrum), white oak (Quercus alba), chestnut oak (Q. prinus), black oak (Q. velutina), blackgum (Nyssa sylvatica), sourwood (Oxydendrum arboreum), and tulip poplar (Liriodendron tulipifera), with occasional dogwood (Cornus florida) and northern red oak (Q. rubra). Understory is absent.

The high-fertility hardwood stand is located in a sinkhole depression on the Tarklin series soil, a Typic Fragiudult. A detailed soil description is given in Table 2. Vegetation is of the yellow-poplar type described by Grigal and Goldstein (1971). Species consist primarily of tulip poplar (Liriodendron tulipifera) with occasional red maple (Acer rubrum), white oak (Quercus alba), black locust (Robinia pseudoacacia), persimmon (Diospyros virginiana), black cherry (Prunus serotina) and Carolina buckthorn (Rhamnus caroliniana). Understory consists of dogwood (Cornus florida), occasional eastern red cedar (Juniperus virginiana) and Japanese honeysuckle (Lonicera japonica).

Thompson Site

The Thompson site is located in the western foothills of the Cascade Mountains near Landsburg, Washington. The climate is of the cool, maritime type with cool, dry summers and wet, moderate winters. Mean annual temperature is $9.8^{\circ} \mathrm{C}$ and mean annual precipitation is $136 \mathrm{~cm}$, most of which falls as rain between October and March. Soil parent material at the site consists of glacial tills and outwash. 
Table 2. Profile description for Tarklin series soil

\begin{tabular}{|c|c|c|}
\hline Horizon & $\begin{array}{l}\text { Depth } \\
(\mathrm{cm})\end{array}$ & Description \\
\hline 01 & $7-2.5$ & $\begin{array}{l}\text { Partially decomposed hardwood and } \\
\text { honeysuckle litter }\end{array}$ \\
\hline 02 & $2.5-0$ & $\begin{array}{l}\text { Unrecognizably decomposed litter } \\
\text { and humus }\end{array}$ \\
\hline A1 & $0-8$ & $\begin{array}{l}\text { Dark grayish-brown (10 yr } 4 / 2) \\
\text { cherty silt loam; weak granular } \\
\text { structure; very friable; abundant } \\
\text { roots; smooth boundary }\end{array}$ \\
\hline$A p$ & $8-18$ & $\begin{array}{l}\text { Dark yellowish-brown }(10 \text { yr } 4 / 4) \\
\text { cherty silt loam; weak fine } \\
\text { granular structure; friable; many } \\
\text { roots; gradual smooth boundary }\end{array}$ \\
\hline BT & $18-32$ & $\begin{array}{l}\text { Dark grayish-brown (10 yr } 4 / 2) \\
\text { cherty silt loam; medium subangular } \\
\text { blocky structure; friable; } \\
\text { occasional roots; gradual wavy } \\
\text { boundary }\end{array}$ \\
\hline $\mathrm{B} 2$ & $32-50$ & $\begin{array}{l}\text { Yellowish-brown }(10 \text { yr } 5 / 4) \text { cherty } \\
\text { silt loam; medium subangular blocky } \\
\text { structure; friable to firm; } \\
\text { occasional roots; abrupt clear } \\
\text { boundary }\end{array}$ \\
\hline B3 & $50+$ & $\begin{array}{l}\text { Brownish-yellow (10 yr } 6 / 8) \text { cherty } \\
\text { silt loam; mottles common; angular } \\
\text { blocky structure; very firm, } \\
\text { compact; brittle; roots rare }\end{array}$ \\
\hline
\end{tabular}


Ablation and lodgement tills have developed into the Alderwood series, the soil used in this study, whereas outwash material has developed into the Everett series.

The study sites are located on a small drumlin dominated by the Alderwood series. A detailed description of the Alderwood soil is given in Table 3.

Vegetation consists of a naturally regenerated, 48-year-old red alder (Alnus rubra) stand surrounded by a 48-year-01d plantation of Douglas-fir (Pseudotsuga menziesii). Perrenial understory in the red alder stand consists predominantly of sword fern (Polystichum munitum) with occasional western hemlock (Tsuga heterophylla), huckleberry (Vaccinium parviflorum), vine maple (Acer circinatum), Oregon grape (Berberis nervosa), and elderberry (Sambucus callicarpa). Understory in the Douglas-fir stand is much less predominant and consists of salal (Gualtheria shallon), huckleberry (Vaccinium parviflorum), with occasional sword fern (Polystichum munitum).

METHODS

At each of the four study sites, four $6 \mathrm{~m} \times 6 \mathrm{~m}$ plots were laid out. At Walker Branch, a soil pit (approximately $0.5 \mathrm{~m} \times 0.75 \mathrm{~m}$ at the surface) was dug in the center of each plot and at the Thompson site, a 1 arger soil pit (approximately $1 \mathrm{~m} \times 2.5 \mathrm{~m}$ at the surface) was dug between pairs of plots. Soil samples were taken proportionally by horizon from the pit walls prior to lysimeter installation, the latter being placed at depths of $8 \mathrm{~cm}$ and at $38 \mathrm{~cm}$ below the A-B horizon boundary (keeping the depth of B horizon a constant). After four months 
Table 3. Profile description for the Alderwood series soila

\begin{tabular}{|c|c|c|}
\hline Horizon & $\begin{array}{l}\text { Depth } \\
(\mathrm{cm})\end{array}$ & Description \\
\hline 01 & $3-2$ & Partially decomposed litter \\
\hline 02 & $2-0$ & $\begin{array}{l}\text { Unrecognizably decomposed litter } \\
\text { and humus }\end{array}$ \\
\hline A & $0-15$ & $\begin{array}{l}\text { Brown }(10 \text { yr } 4 / 3) \text { sandy loam; } \\
\text { moderate medium granular structure; } \\
\text { friable; scattered concretions; } \\
\text { clear, wavy boundary; many roots }\end{array}$ \\
\hline B21 & $15-30$ & $\begin{array}{l}\text { Pale brown }(10 \text { yr } 6 / 3) \text { sandy loam; } \\
\text { weak medium subangular blocky } \\
\text { structure; friable; scattered } \\
\text { concretions; clear, wavy boundary; } \\
\text { many roots }\end{array}$ \\
\hline B 22 & $30-60$ & $\begin{array}{l}\text { Light yellowish-brown (10 yr } 6 / 4) \\
\text { gravelly sandy loam; weak medium } \\
\text { subangular blocky structure; } \\
\text { friable; clear, wavy boundary; } \\
\text { occasional roots }\end{array}$ \\
\hline B 22 & $60-85$ & $\begin{array}{l}\text { Very pale brown }(10 \text { yr } 7 / 3) \\
\text { graveliy, sandy loam; weak medium } \\
\text { subangular blocky structure; } \\
\text { friable; clear, wavy boundary; } \\
\text { occasional roots }\end{array}$ \\
\hline C & $85+$ & $\begin{array}{l}\text { Dark gray }(10 \text { yr } 4 / 1) \text { gravelly, } \\
\text { sandy loam; strong medium platy } \\
\text { structure to massive; roots rare }\end{array}$ \\
\hline
\end{tabular}

a Source: Cole and Gesse1, 1968. 
of monitoring the lysimeter waters, treatments were applied to three of the four plots, the fourth being left as control. Treatments included (1) sufficient urea-N to double litter $N$ content, (2) sufficient sawdust to double litter weight, and (3) $0.5 \mathrm{eq} / \mathrm{m}^{2} \mathrm{NaH}_{2} \mathrm{PO}_{4}, \mathrm{Na}_{2} \mathrm{SO}_{4}, \mathrm{NaCl}$, and $\mathrm{NaNO}_{3}$ salts. Effects of these treatments on soil solution composition will be reported el sewhere.

Soil samples from lysimeter pits were analyzed for bulk density and percent gravel where needed and for the chemical constituents as outlined in Table 4. To ensure comparability of results, analyses were divided between ORNL and the University of Washington to allow all analyses of each kind to be done at one place by the same personnel.

\section{RESULTS AND DISCUSSION}

Expressed as percentages of the less than $2-\mathrm{mm}$ size fraction, free Fe and $A 1$ in the Alderwood soils exceeded that in the Oak Ridge soils with the exception of the Fullerton B1 and B2 horizons (Tables 5 and 6 ). The relatively low Fe values in the Tarklin $B$ horizon may be the result of wet, anoxic conditions created by the impermeable fragipan immediately below it. During rainy portions of the year, very moist conditions prevail immediately above the fragipan and a perched water table above the B2 horizon is common following storm events.

The profiles of free $\mathrm{Fe}$ and $\mathrm{Al}$ in the Alderwood and Walker Branch soils reflect different degrees and patterns of weathering. The relatively young (ca. 10,000 years) Alderwood soils appear to be experiencing buildups of free $\mathrm{Fe}$ and $\mathrm{Al}$ from the surface downward, whereas surface horizons of the much older (ca. $2 \times 10^{8}$ years) 
Table 4. Methods used in Soil Chemical Analyses

1. Water-soluble anions - Shake $10 \mathrm{~g}$ air-dried soil with $50 \mathrm{ml} \mathrm{H}_{2} \mathrm{O}$ for $1 \mathrm{~h}$. Analyze for $\mathrm{PO}_{4}, \mathrm{SO}_{4}, \mathrm{Cl}, \mathrm{NO}_{3}$ on Autoanalyzer.

2. Absorbed anions - Subtract soluble anions from results of the following analyses:

A. For $\mathrm{SO}_{4}^{2-}, \mathrm{NO}_{3}^{-}$, and $\mathrm{Cl}^{-}$:

Shake $10 \mathrm{~g}$ air-dried soil with $50 \mathrm{ml} \mathrm{NaH} \mathrm{PO}_{4}$ containing $1000 \mathrm{ppm} P$ for $1 \mathrm{~h}$ and analyze as follows:

1. $\mathrm{SO}_{4}^{2-}$ : determine by barium chlorinate analysis (Bertolacini and Barney, 1957)

2. $\mathrm{NO}_{3}:$ Autoanalyzer

3. $\mathrm{Cl}^{-}$: Autoanalyzer

B. For $\mathrm{PO}_{4}$ - -analyze with Bray $\mathrm{P}$ (No. 2) according to Black (1965) except shaken for $20 \mathrm{~min}$. $\mathrm{PO}_{4}$ then analyzed on Autoanalyzer.

3. Free $\mathrm{Fe}$ and $\mathrm{Al}$ by Citrate buffer-dithionite extraction (Jackson, 1973) without prior organic matter removal

4. Cation exchange capacity (CEC) and exchangeable cations by extraction with $1 \mathrm{~N} \mathrm{NH}_{4} \mathrm{Cl}$ in Buchner funnels followed by an alcohol rinse and an extraction with $\mathrm{NaCl}$. Exchangeable cations determined by atomic absorption on $\mathrm{NH}_{4} \mathrm{Cl}$ extract, $\mathrm{CEC}$ by Autoanalyzer analyses for $\mathrm{NH}_{4}$ on $\mathrm{NaCl}$ extract.

5. Total $\mathrm{N}$ by macro-Kjeldahl digestion,

Total $C$ by LECO combustion

6. $\mathrm{pH}$ in 1:1 soil :water paste 
Table 5. Values for $p H$, free $F e$ and $A 1$, Bray $P$ and anion concentrations in soils from the Oak Ridge sites ${ }^{a}$

\begin{tabular}{|c|c|c|c|c|c|c|c|c|c|}
\hline $\begin{array}{l}\text { Horizon } \\
\text { and depth } \\
(\mathrm{cm})\end{array}$ & $\mathrm{pH}$ & $\begin{array}{l}\mathrm{Fe} \\
(\%)\end{array}$ & $\begin{array}{l}A 1 \\
(\%)\end{array}$ & Bray $p^{C}$ & $\begin{array}{c}\text { Sol uble } \\
\mathrm{PO}_{4}^{-}{ }_{4}^{\mathrm{P}}\end{array}$ & $\begin{array}{l}\text { Adsorbed } \\
\mathrm{SO}_{4}^{-} \mathrm{S}^{\mathrm{C}}\end{array}$ & $\begin{array}{c}\text { Sol uble } \\
\mathrm{SO}_{4}^{-} \mathrm{S}\end{array}$ & $\begin{array}{c}\text { Soluble } \\
\mathrm{Cl}\end{array}$ & $\underset{\mathrm{NO}_{3}^{-} \mathrm{N}}{\mathrm{Sol} \text { uble }}$ \\
\hline & & & & \multicolumn{6}{|c|}{$(p p m)$} \\
\hline \multicolumn{10}{|c|}{ Iarklin } \\
\hline $\begin{array}{l}\text { A1 }(0-7) \\
\text { Ap }(0-18) \\
\text { B1 }(19-32) \\
\text { B2 }(32-50)\end{array}$ & $\begin{array}{c}4.60 \\
(0.05) \\
4.95 \\
(0.19) \\
4.73 \\
(0.06) \\
4.66 \\
(0.08)\end{array}$ & $\begin{array}{c}0.51 \\
(0.01) \\
0.47 \\
(0.009) \\
0.63 \\
(0.03) \\
0.75 \\
(0.05)\end{array}$ & $\begin{array}{c}0.15 \\
(0.004) \\
0.18 \\
(0.0001) \\
0.18 \\
(0.006) \\
0.17 \\
(0.01)\end{array}$ & $\begin{array}{c}13.28 \\
(1.80) \\
27.90 \\
(10.48) \\
2.68 \\
(0.48) \\
2.88 \\
(2.18)\end{array}$ & $\begin{array}{c}0.39 \\
(0.71) \\
0.77 \\
(0.25) \\
0.53 \\
(0.24) \\
0.10 \\
(0.07)\end{array}$ & $\begin{array}{l}2.88 \\
(1.33) \\
1.52 \\
(1.52) \\
20.10 \\
(9.89) \\
42.50 \\
(7.95)\end{array}$ & $\begin{array}{l}31.50 \\
(2.55) \\
22.38 \\
(6.87) \\
26.73 \\
(9.06) \\
10.48 \\
(1.72)\end{array}$ & $\begin{array}{c}19.43 \\
(4.52) \\
30.45 \\
(9.53) \\
95.15 \\
(39.60) \\
9.09 \\
(5.94)\end{array}$ & $\begin{array}{c}0.50 \\
(0.0001) \\
0.18 \\
(0.05) \\
0.29 \\
(0.11) \\
0.14 \\
(0.04)\end{array}$ \\
\hline \multicolumn{10}{|c|}{ Fullerton } \\
\hline $\begin{array}{l}\text { A1 }(0-7) \\
\text { A2 }(0-38) \\
\text { B1 }(38-50) \\
\text { B2 }(50-80)\end{array}$ & $\begin{array}{c}4.60 \\
(0.11) \\
4.88 \\
(0.05) \\
4.58 \\
(0.04) \\
4.75 \\
(0.17)\end{array}$ & $\begin{array}{c}0.94 \\
(0.08) \\
0.49 \\
(0.03) \\
1.10 \\
(0.09) \\
2.49 \\
(0.14)\end{array}$ & $\begin{array}{c}0.39 \\
(0.03) \\
0.17 \\
(0.01) \\
0.20 \\
(0.02) \\
0.33 \\
(0.009)\end{array}$ & $\begin{array}{c}6.97 \\
(1.28) \\
2.28 \\
(0.16) \\
0.42 \\
(0.04) \\
0.20 \\
(0.04)\end{array}$ & $\begin{array}{c}0.23 \\
(0.03) \\
0.13 \\
(0.10) \\
0.02 \\
(0.006) \\
0.08 \\
(0.07)\end{array}$ & $\begin{array}{c}8.80 \\
(2.45) \\
30.73 \\
(5.32) \\
63.60 \\
(10.00) \\
94.35 \\
(23.56)\end{array}$ & $\begin{array}{c}33.54 \\
(3.82) \\
16.50 \\
(2.63) \\
9.08 \\
(1.64) \\
5.17 \\
(2.04)\end{array}$ & $\begin{array}{l}15.90 \\
(2.09) \\
14.23 \\
(4.38) \\
4.36 \\
(2.28) \\
2.25 \\
(0.56)\end{array}$ & $\begin{array}{c}0.45 \\
(0.05) \\
0.13 \\
(0.01) \\
0.14 \\
(0.06) \\
0.07 \\
(0.006)\end{array}$ \\
\hline
\end{tabular}

atandard deviations in parentheses $(<2 \mathrm{~mm}$ fractions).

barithmetic mean of $\mathrm{H}^{+}$.

${ }^{\mathrm{C}}$ Soluble component subtracted.

Table 6. Values for $\mathrm{pH}$, free $\mathrm{Fe}$ and $\mathrm{Al}, \mathrm{Bray} \mathrm{P}$, and anion concentrations in soils from the Thompson sitesa

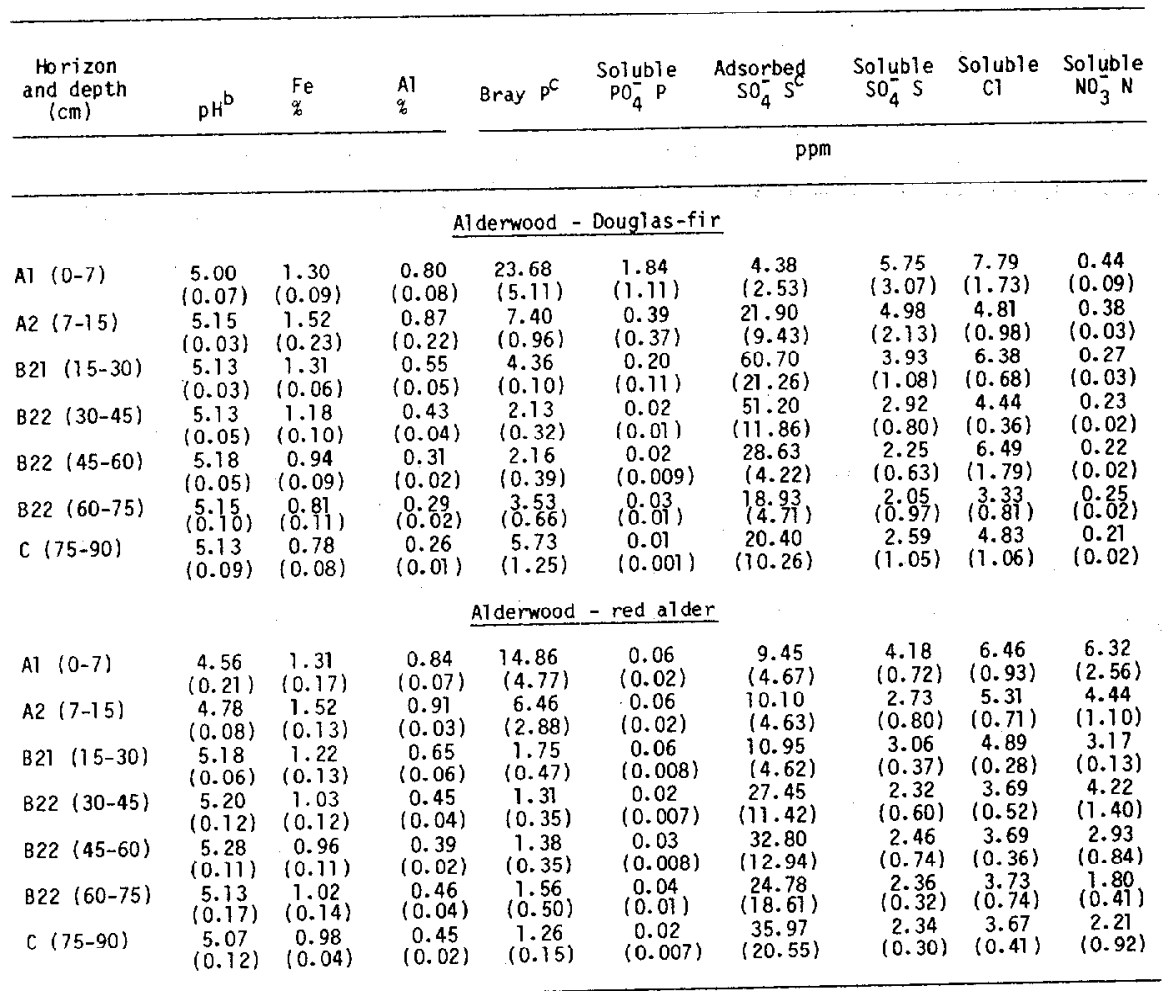

a Standard deviations in parentheses $(<2 \mathrm{~mm}$ fraction).

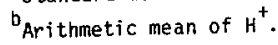

${ }^{\mathrm{C}}$ Soluble component subtracted. 
Tarklin and Fullerton soils are relatively depleted in Fe presumably because of both clay and soluble Fe migration to the $B$ horizons.

Both the Tarklin and Fullerton soils are slightly more acid than the Alderwood soils, except in the Al and B2 horizons of the red alder soil (Table 5 and 6 ). The reason for the difference in A-horizon $\mathrm{pH}$ between the Douglas-fir and red alder soils appears to be due to lower base saturation in the latter (Table 7).

Both soluble and Bray phosphorus (P) were highest in A horizons and declined rapidly with depth in all cases. The red alder site had significantly less soluble and Bray $P$ than the Douglas-fir site, perhaps because of $\mathrm{N}$-induced $\mathrm{P}$ immobilization (broader $\mathrm{N}: \mathrm{P}$ ratio) in the alder site. The Tarklin soil contained more soluble and Bray $P$ than the Fullerton soil, and $P$ status by these indices appeared to be the most striking nutritional difference between these soils among the analyses conducted (Tables 6 and 8 ).

Adsorbed sulfate increased and soluble sulfate decreased with depth in both the Tarklin and Fullerton soils. The sulfate pattern in the Fullerton soil was very similar to that reported previously (Johnson and Henderson, 1979). In their respective $B 1$ and $B 2$ horizons, the Tarklin soil contained considerably less adsorbed sulfate but more soluble sulfate than the Fullerton soil; this probably reflects differences in adsorption of sulfate due to differences in free $\mathrm{Fe}$ and Al concentration. The same general pattern of decreasing soluble sulfate and increasing adsorbed sulfate with depth was observed in the Alderwood soils, but the relationship between these patterns and those of free $\mathrm{Fe}$ and $\mathrm{Al}$ with depth was not consistent; i.e., soluble sulfate 
Table 7. Bulk density (Ob), percent gravel, N, C, C:N ratio, cation exchange capacity (CEC), exchangeable cations and percent base saturation (BS) in soils from the Oak Ridge sitea

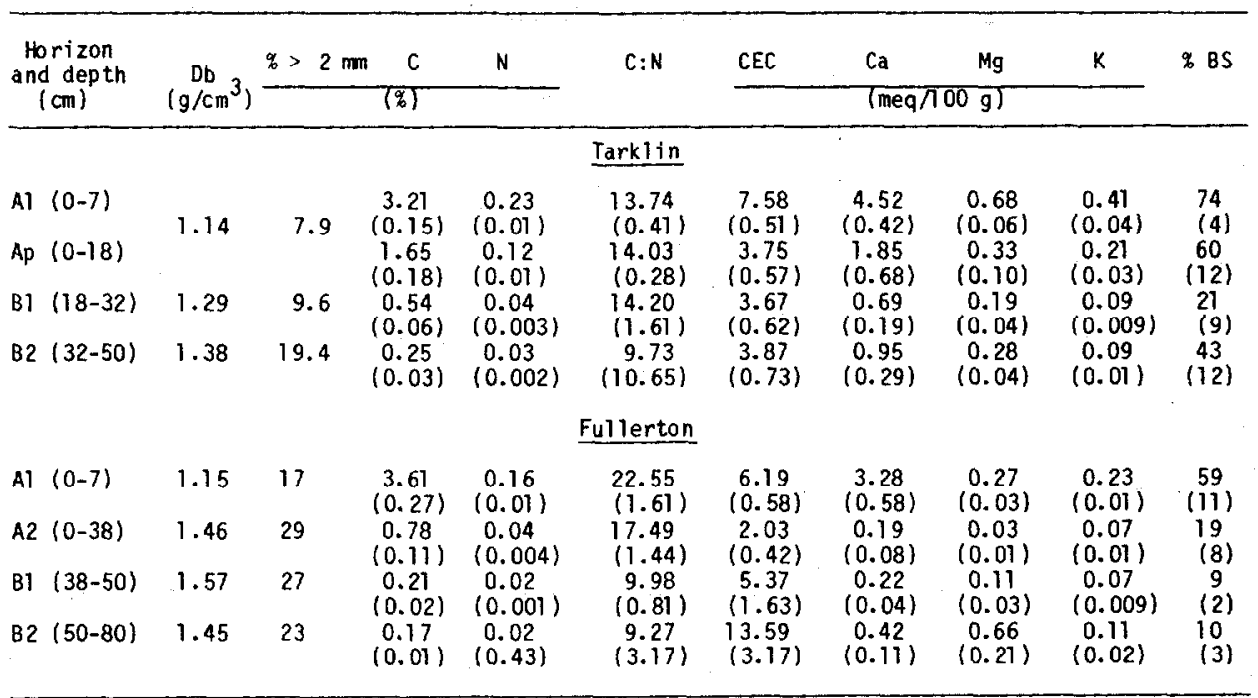

astandard deviations in parentheses ( $<2 \mathrm{~mm}$ fraction).

Table 8. Bulk density (Db), percent gravel, N, C, C:N ratio, cation exchange capacity (CEC), exchangeable cations, and percent base saturation (BS) in soils from the Thompson sitea

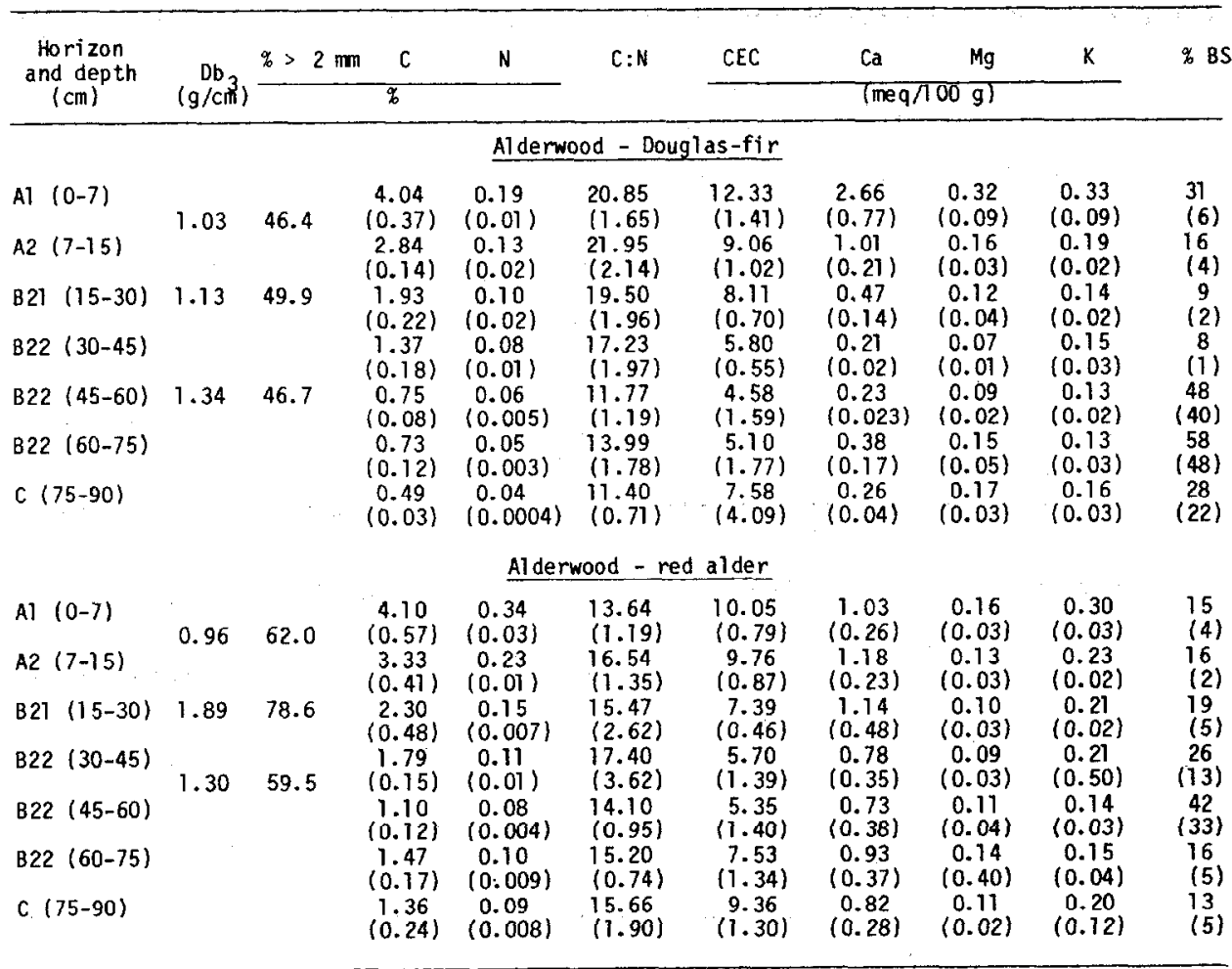

astandard deviations in parentheses $(<2 \mathrm{~mm}$ fraction $)$. 
was relatively high and adsorbed sulfate was relatively low in Al and $\mathrm{A} 2$ horizons, even though free $\mathrm{Fe}$ and $\mathrm{Al}$ were relatively high (Table 6). This was probably due to the presence of high organic matter in these horizons (Table 8 ), which is thought to block sulfate adsorption sites (Johnson et al., 1979, 1980).

No adsorbed nitrate or chloride was detected in any soils tested (i.e., differences between phosphate and water extractions were not statistically significant). The general pattern of both nitrate and chloride was a decreasing concentration with depth. The Tarklin soil had the highest chloride concentrations followed by the Fullerton and the two Alderwood soils, the latter two being quite comparable to one another in this regard. Nitrate concentrations in the Fullerton, Tarklin, and Alderwood-Douglas-fir were comparable whereas the presence of red alder apparently resulted in much higher nitrate concentrations in that soil.

Carbon concentrations were comparable in the Al horizons of the Tarklin, Fullerton, Douglas-fir, and red alder soils, respectively, but in each case the richer soil (Tarklin and red alder) had higher $C$ than the poorer soil (Fullerton and Douglas-fir) in deeper horizons (Tables 7 and 8). The richer soils were higher in total $\mathrm{N}$ than the poorer soils throughout their respective profiles, but $\mathrm{C}: \mathrm{N}$ ratios showed curious crossovers with depth: the richer soils had narrower $C: N$ ratios than the poorer soils at the surface, but the reverse was true in deeper horizons (Tables 7 and 8 ). In the case of the red alder soil, the $\mathrm{C}: \mathrm{N}$ ratio increases significantly from the Al to deeper horizons, and the same trend, though less pronounced, is evident in the Tarkl in soil. 
Arithmetically this effect is due to the higher carbon concentrations in deeper horizons of the richer soils, but a full mechanistic explanation for this is not yet available.

Cation exchange capacity (CEC) is lower but base saturation is higher in the Al horizons of the Oak Ridge soils as compared to the Alderwood soils. This would appear to conflict with $\mathrm{pH}$ data, but the explanation probably lies in the fact that $\mathrm{NH}_{4} \mathrm{Cl}$ extraction does not measure $\mathrm{pH}$-dependent $\mathrm{CEC}$, and, in this case at least, does not reflect the relative degree of soil acidity. Raising the $\mathrm{pH}$ of the Oak Ridge soils, either by treatments in the field (i.e., urea application) or by using the standard ammonium acetate extraction would no doubt produce higher CEC and lower base saturation values. Free Fe and Al oxide surfaces and organic matter are known to contribute to this $\mathrm{pH}$-dependent CEC (Coleman and Thomas, 1967).

There was a general pattern of rapidly decreasing exchangeable cation concentration with depth in all soils except the Alderwood-red alder. The latter soil had lower calcium (Ca) levels than its Douglas-fir counterpart in the Al horizon but higher Ca levels in subsurface horizons (Table 8). Similarly, the Tarklin soil had much higher Ca levels than the Fullerton soil in subsurface horizons even though Al horizon Ca levels were fairly comparable.

With regard to the hypotheses being tested in the current study, the soils chosen provide adequate contrasts in $\mathrm{N}$ status and in free $\mathrm{Fe}$ and Al content, but the patterns in the latter were not as expected. The younger Alderwood soils had higher free $\mathrm{Fe}$ in surface horizons and higher free Al in nearly all horizons than the older Oak Ridge soils. 
The Tarklin soil was a major exception to the pattern depicted in Fig. 1, with its very low free Fe and Al content throughout the soil, but the Fullerton $B 2$ horizon fell in its predicted place with regard to $i$ ts high free $\mathrm{Fe}$. These somewhat unexpected patterns do not preclude the testing of any hypotheses regarding the relationships between free Fe and $A l$ and anion mobility, however, and experiments are therefore proceeding according to original plans. It should also be noted that if concentrations are expressed on a whole-soil basis, taking the weight of gravel $(\%>2 \mathrm{~mm})$ fraction into account (but assuming it to be chemically inert), the free $\mathrm{Fe}$ and $A l$ in the Alderwood $B$ horizons fall to values comparable to those in the Tarklin $B$ horizon and below those of the Fullerton B horizon by virtue of the lower gravel content of the latter soils (Table 9). The relative $\mathrm{N}$ contents and $\mathrm{C}: \mathrm{N}$ ratios between the two Oak Ridge and two Alderwood soils remain unchanged according to this calculation, although the greater gravel content in the Alderwood-red alder soil reduced its content proportionally more than in the Douglas-fir soil. Since field studies do involve C, N, and anion salt applications to intact soils, the data in Table 9 may be more relevant to the leaching responses following field manipulations than data for the nongravel fraction only. 
Table 9. Percent free Fe, Al, C, and $N$ in Tarklin, Fullerton and Alderwood soils on a whole-soil basts

\begin{tabular}{|c|c|c|c|c|c|}
\hline Horizon & $\mathrm{Fe}$ & A1 & $C$ & $\mathrm{~N}$ & $\mathrm{C}: \mathrm{N}$ \\
\hline & \multicolumn{5}{|c|}{ Tarkl in } \\
\hline $\mathrm{Al}$ & 0.47 & 0.14 & 2.95 & 0.21 & 13.74 \\
\hline$A p$ & 0.43 & 0.17 & 1.52 & 0.11 & 14.03 \\
\hline$B T$ & 0.57 & 0.16 & 0.49 & 0.04 & 14.20 \\
\hline \multirow[t]{2}{*}{ B2 } & 0.61 & 0.14 & 0.20 & 0.02 & 9.73 \\
\hline & \multicolumn{5}{|c|}{ Fullerton } \\
\hline A1 & 0.78 & 0.32 & 3.00 & 0.13 & 22.25 \\
\hline $\mathrm{A} 2$ & 0.36 & 0.12 & 0.55 & 0.03 & 17.49 \\
\hline B1 & 0.80 & 0.15 & 0.15 & 0.01 & 9.98 \\
\hline \multirow[t]{2}{*}{ B2 } & 1.92 & 0.25 & 0.13 & 0.02 & 9.27 \\
\hline & \multicolumn{5}{|c|}{ Alderwood - Douglas-fir } \\
\hline Al & 0.71 & 0.44 & 2.17 & 0.10 & 20.85 \\
\hline $\mathrm{A} 2$ & 0.83 & .48 & 1.52 & 0.07 & 21.95 \\
\hline B21 & 0.72 & .28 & 0.99 & 0.65 & 19.50 \\
\hline B22 & 0.60 & 0.22 & 0.73 & 0.04 & 17.23 \\
\hline B22 & 0.50 & 0.17 & 0.40 & 0.03 & 11.77 \\
\hline \multirow[t]{2}{*}{ B22 } & 0.43 & 0.15 & 0.39 & 0.03 & 13.99 \\
\hline & \multicolumn{5}{|c|}{ Al derwood - red alder } \\
\hline A1 & 0.50 & 0.32 & 1.56 & 0.13 & 13.64 \\
\hline A2 & 0.50 & 0.35 & 1.27 & 0.09 & 16.54 \\
\hline B21 & 0.27 & 0.15 & 1.27 & 0.03 & 15.47 \\
\hline B 22 & 0.53 & 0.23 & 0.92 & 0.06 & 17.40 \\
\hline B22 & 0.48 & 0.20 & 0.57 & 0.04 & 14.10 \\
\hline B22 & 0.53 & 0.24 & 0.76 & 0.05 & 15.20 \\
\hline
\end{tabular}




\section{LITERATURE CITED}

Bertolacini, R. J., and J. E. Barney, II. 1957. Colorimetric determination of sulfate with Sarium chloranilate. Anal. Chem. 29:281-283.

Black, C. A., and others (eds.). 1965. Methods of Soil Analysis. Part 2. Agronomy No. 9. American Society of Agronomy, Madison, Wisconsin.

Cole, D. W., and S. P. Gessel. 1968. Cedar River Research - A program for studying the pathways, rates, and processes of elemental cycling in a forest ecosystem. Contribution No. 4. Institute of Forest Products, College of Forest Resources, University of Washington, Seattle.

Coleman, N. T., and G. W. Thomas. 1967. The basic chemistry of soil acidity. pp. 1-41. IN Pearson, R. W., and F. Adams (eds.), Soil Acidity and Liming. Agronomy No. 12. American Society of Agronomy, Madison, Wisconsin.

Grigal, D. F., and R. A. Goldstein. 1971. An integrated ordinationclassification analysis of an intensively sampled oak-hickory forest. J. Ecol . 59:481-492.

Henderson, G. S., A. Hunley, and W. Selvidge. 1977. Nutrient discharge from Walker Branch Watershed. pp. 307-320. IN Corre11, T. L., (ed.), Watershed Research in North America, Vol. I. Smithsonian Institution, Chesapeake Bay Center for Environmental Studies, Edgewater, Maryland. 
Jackson, M. L. 1973. Soil Chemical Analysis - Advanced Course. 2nd

Ed. Copyright by M. L. Jackson.

Johnson, D. W., D. W. Cole, and S. P. Gessel. 1979. Acid precipitation and soil sulfate adsorption in a tropical and in a temperate forest soil. Biotropica $11: 38-42$.

Johnson, D. W., and G. S. Henderson. 1979. Sulfate adsorption and sulfur fractions in a highly-weathered soil under a mixed deciduous forest. Soil Sci. 128:34-40.

Johnson, D. W., J. W. Hornbeck, J. M. Kelly, W. T. Swank, and D. E. Todd. 1980. Regional patterns of soil sulfate accumulation: Relevance to ecosystem sulfur budgets. pp. 507-520. IN Shriner, D. S., C. R. Richmond, and S. E. Lindberg (eds.), Environmental and Health Effects of Atmospheric Sulfur Deposition. Ann Arbor Science, Ann Arbor, Michigan. 
ORNL/TM-7646

\section{INTERNAL DISTRIBUTION}

1-2. S. I. Auerbach

3. M. G. Browman

4-7. D. W. Johnson

8. J. M. Kelly

9. R. J. Luxmoore

10. D. D. Richter

11. B. P. Spalding

12. T. Tamura
13-17. D. E. Todd

18. J. B. Waide

19. Central Research Library

20-30. ESD Library

31-32. Laboratory Records Department

33. Laboratory Reocrds, ORNL-RC

34. ORNL Y-12 Technical Library

35. ORNL Patent office

\section{EXTERNAL DISTRIBUTION}

36. G. Abrahamsen, Norwegian Forest Research Institute, P.0. Box 61-1432 AS-NLH Norway

37. J. T. Callahan, Deputy Director, Ecosystem Studies Program, National Science Foundation, Washington, D.C.

38-42. D. W. Cole, College of Forest Resources, AR-10, University of Washington, Seattle, Washington 98195

43. William J. Coppoc, Texaco, Inc., P.0. Box 509, Beacon, New York 12508

44. C. S. Cronan, Dept. of Botany and Plant Pathology, Univ. of Maine, Orono, Maine 04469

45. N. R. Glass, National Ecological Research Laboratory, Environmental Protection Agency, 200 S. W. 35th St., Corvallis, Oregon 97330

46. C. C. Grier, College of Forest Resources AR-10, University of Washington, Seattle, Washington 98195

47. W. F. Harris, Program Manager, Ecosystem Studies Program, National Science Foundation, Washington, D.C.

48. G. S. Henderson, School of Forestry, Univ. of Missouri, Columbia, Missouri 65201

49. J. W. Hornbeck, Forestry Sciences Lab., Northeastern Forest Experiment Station, P.0. Box 640, Durham, New Hampshire

50-54. F.W. Horng, College of Forest Resources, AR-10 University of Washington, Seattle, Washington 98195

55. J. W. Huckabee, Environmental Assessment Dept., Electric Power Research Institute, P.0. Box 10412, Palo Alto, California 94303

56. J. Lee, Corvalli is Environmental Research Lab., 200 S. W. 35th St., Corvallis, Oregon 97330

57. R. A. Lewis, Environmental Programs, Division of Biomedical and Environmental Research, Dept. of Energy, Washington, D.C. 20545

58. Helen McCammon, Director, Division of Environmental Research, Department of Energy, Washington, D.C. 20545

59. J. G. McColl, Dept. of Soil Science and Plant Nutrition, Univ. of California, 108 Hilgard Hall, Berkeley, CA 94720 
60. W. M. McFee, Agronomy Dept., Purdue University, West Lafayette, Indiana 47906

61. Haydn H. Murray, Director, Department of Geology, Indiana University, Bloomington, IN 47405

62. William S. Osburn, Jr., Division of Ecological Research, Office of Health and Environmental Research, Department of Energy, Washington, DC 20545

63. Douglas Pewlitt, Acting Director, Office of Energy Research, Department of Energy, Washington, DC 20545

64. Paul G. Risser, Dept. of Botany and Microbiology, University of Ok 1ahoma, Norman, Oklahoma 73019

65. H. M. Seip, Central Institute for Industrial Research, Forsknings v. 1, P. B. 350 Blindern, 0slo 3, Norway

66. George R. Shepherd, Department of Energy, Room 4G-052, MS 4G-085, Forestal B1dg., Washington, DC 20545

67. B. R. Singh, Dept. of Soil Fertility and Management, Agricultural University of Norway, Box 28, N-1432, As-NLH, Norway

68. W. T. Swank, Coweeta Hydrologic Lab., P.0. Box 601, Franklin, North Carolina 28734

69-73. H. Van Miegroet, College of Forest Resources, AR-10, University of Washington, Seattle, Washington 98195

74. P. M. Vitousek, Dept. of Botany, Univ. of North Carolina, Chapel Hill, North Carolina

75. Richard H. Waring, Dept. of Forest Science, Oregon State University, Corvallis, Oregon 97331

76. Robert L. Watters, Office of Health and Environmental Research, Department of Energy, Washington, DC 20545

77. Robert $W$. Wood, Office of Health and Environmental Research, Bldg. GTN, Germantown, MD 20767

78. Office of Assistant Manager for Energy Research and Development, Oak Ridge Operations, Department of Energy

79-105. Technical Information Center, DOE, Oak Ridge, Tennessee 